Прегледни рад/ Reviewing paper

УДК/UDC: 005.322:316.46

005.96

338.486.22(497.11)

doi:10.5937/bizinfo1901029D

\title{
THE IMPACT OF AUTHENTIC LEADERSHIP ON THE COMMITMENT OF EMPLOYEES IN TRAVEL AGENCIES IN THE REPUBLIC OF SERBIA
}

\section{UTICAJ AUTENTIČNOG LIDERSTVA NA POSVEĆENOST ZAPOSLENIH U TURISTIČKIM AGENCIJAMA U REPUBLICI SRBIJI}

\author{
Sandra Dramićanin ${ }^{1}$ \\ University of Kragujevac, Faculty of Hotel Managment and Tourism in \\ Vrnjačka Banja
}

Abstract: Authentic leadership is the highest and most powerful level of leadership. An authentic leader is expected to create an atmosphere of security, loyalty and trust among members of the organization. Only under these circumstances can an individual and group within the organization progress. An authentic leader places his interest in the last place, and their environment and employees are motivated in the right way that what they know and love, can do in the best possible way. The purpose of the paper is to analyze the characteristics of the authentic leaders and their impact on the commitment of employees. The aim of the paper is to quantify the influence of authentic leaders on the commitment of employees in travel agencies. The results show that leaders' self-awareness, internalized moral and transparency directly affect the commitment of employees to travel agencies. Key words: authentic leadership, dimensions of authentic leadership, employee commitment, travel agencies

Sažetak: Autentično liderstvo predstavlja najviši i najmoćniji nivo liderstva. Od autentičnog lidera se očekije da napravi atmosferu sigurnosti, lojalnosti $i$ poverenja među članovima organizacije. Samo pod ovim uslovima pojedinac

${ }^{1}$ sandradramicanin@ hotmail.com 
i grupa unutar organizacije mogu da napreduju. Autentičan lider postavlja svoj interes na poslednje mesto, a svoje okruženje i zaposlene na pravi način motiviše da ono što znaju i vole, rade na najbolji mogući način. Svrha rada je analiza karakteristika autentičnih lidera $i$ njihov uticaj na posvećenost zaposlenih. Cilj rada je kvantifikacija uticaja autentičnih lidera na posvećenost zaposlenih u turističkim agencijama u Republici Srbiji. Rezultati pokazuju da liderova samosvest, internalizovani moral i transparentnost, direktno utiču na posvećenost zaposlenih u turističkim agencijama.

Ključne reči: autentično liderstvo, dimenzije autentičnog liderstva, posvećenost zaposlenih, turističke agencije

\section{INTRODUCTION}

Leadership, as a process of influencing people to engage in achieving a particular goal, is a multidisciplinary and extremely complex phenomenon. The essence of leadership is the realization of the potential of the leaders' personality and the employees who they lead (Menken, 2012) and it is located in the ability of the leader to create and manage the vision and influence employees to work towards achieving the vision. Leaders represent the drive force of each organization. They primarily understand themselves, then other individuals, the functioning of the organization and the environment in which they operate. Different leaders' competences, including readiness for learning and improvement, are also significant for the leadership process and for leaders. It is understood that a leader affects employees and that they also have an impact on him. The leader is a central figure, but without a group he would not have anybody to manage. The leader transfers his own interpretation of reality to his employees, and they see the organization, tasks and processes through the prism of their leader.

Familiar ways and business models and organizational culture are rapidly changing and evolving. Leading an the organization at a time of uncertainty is stressful and puts leadership skills on the limit test. The role and purpose of leadership are becoming questionable and require analysis, definition and redefinition, as well as the development of new skills.

The latest style of leadership that has captured the attention of researchers is an authentic leadership based on originality and a real manager (Northouse, 2017). Authentic leadership is unique and differs from leader to leader. The mode of management of an authentic leader depends on the characteristics and manner of behavior of the individual. An authentic leader is characterized by positive mental abilities, a positive ethical climate, fostering an inner moral perspective, balanced decision-making, quality work with followers and continuous self-development (Ford, 2011). Authentic leaders are aware of their values, quality and beliefs, they are confident, trustworthy, reliable and honest. They focus on building relationships and strengths of employees 
THE IMPACT OF AUTHENTIC LEADERSHIP ON THE COMMITMENT OF EMPLOYEES IN TRAVEL AGENCIES IN THE REPUBLIC OF SERBIA

by expanding their aspects and engaging them so that a positive organizational context is created.

Authentic leadership has an impact on organizational behavior, commitment, satisfaction with superior, job satisfaction and work performance of employees (Milić, 2014). Employee commitment represents a high level of interest, a high level of motivation for performing certain activities, but also the importance that employees attach to it (Ovesni, 2014). Fornes et al. (2008) define the commitment of employees using a theoretical construction that includes two elements: commitment to management and commitment to the organization. Commitment to management is most often determined as the strength of identification with management and internalisation of the value of management, and commitment to the organization as a psychological and emotional connection of employees, that is, the strength of their identification with the goals and values of the organization.

Known ways of working, business models and organizational culture are changing rapidly. Travel agencies have uncertainties in business resulting from accelerated technological advances and require new approach, innovation, agile teams and an authentic way of guiding. Key words for leaders in travel agencies become transparency, cooperation, meaning, creativity and initiative. Even when it is clear on the intellectual level what these values mean, it is difficult to implement them in the work environment in travel agencies. Changes are inevitable, and the question is how to successfully run a travel agency and its teams. Good practice examples show that leaders who are capable of leading high performing teams in travel agencies in times of uncertainty and rapid change have two characteristics: authenticity and conscientious management. Authentic leadership is the basis of a modern approach to travel agencies and directing employees to a common goal.

Starting from the above, the aim of the paper is to determine the influence of authentic leaders on the commitment of employees in travel agencies in the Republic of Serbia. Authentic leaders are perceived through the prism of the following characteristics: self-awareness, transparency in relationships, balanced processing of information and internalized morale (Walumbwa et al., 2008). These characteristics are used to determine the degree to which employee dedication affects and which leader's characteristic has the greatest direct impact.

\section{COMMITMENTOF EMPLOYEES IN TOURISM}

Service delivery implies that production and consumption are simultaneous. For this reason, the service organization is characterized by direct contact and communication between employees and consumers. This characteristic of 
service organizations represents a potential threat to consumer satisfaction, and hence the success of organizations (Blesic et al., 2017). In order to achieve customer satisfaction, the satisfaction and commitment of employees should be the imperative of any service organization, including travel agencies. Commitment represents an attitude that reflects the power of relationships between an organization and employees (Johns, Saks, 2005). Dedication is most often viewed in the context of feelings and beliefs about the overall organization, but it can also be associated with feelings and beliefs about certain units inside and outside the organization, such as a job, a team, a group, an association, a trade union, a profession (commitment to the job, the team, group, association, union, profession) (George, Jones, 2011).

The main components that contribute to employee loyalty and commitment are loyalty to the organization, working conditions, benefits, location, career and status. Positive benefits and involvement of employees in decisionmaking of the organization have the greatest effect when it comes to employee dedication, even more than monetary compensation (Ineson et al., 2013). Employee commitment involves a strong belief in the goals of the organization, investing effort to achieve the set goals and desires for the organization's membership (Porter et al., 1974). Amstrong (1999) explained that the creation of dedicated employees is necessary to create organizational values.

Dedicated employees represent one of the most important factors for the success of travel agencies in the Republic of Serbia. The active role of the leader and the commitment of employees are the necessary conditions for the long-term functioning of travel agencies with predispositions for further growth and development. It is necessary to note that the commitment of employees is largely influenced by leadership (Milić, 2014). Consequently, it is of particular importance that leaders, through their behavior, rhetoric and activities, stimulate employee dedication in order to create conditions for adequate growth and development of travel agencies in the Republic of Serbia in the long run.

One of the most important concerns of companies today is to ensure that leaders reflect visions and strategies and maintain an appropriate organizational climate and employee commitment (Yukl, Tracey, 1992). Dedication has been highlighted as a key component of the success of travel agencies in today's competitive tourism market. High levels of employee dedication positively affect the commitment of people, customer loyalty and the value and performance of the organization (Meyer, 2014). In order to cultivate a culture of employee dedication, the leader should set the basics of designing, measuring and evaluating proactive workplace practices that will help attract and recruit talents with the skills and competencies needed for the 
THE IMPACT OF AUTHENTIC LEADERSHIP ON THE COMMITMENT OF EMPLOYEES IN TRAVEL AGENCIES IN THE REPUBLIC OF SERBIA

growth and sustainability of travel agencies. Leaders can increase employees' commitment and overall productivity of individual employees and the agency. Well-executed and targeted development programs can increase commitment, reduce the percentage of failures and the number of errors as a result of greater competence and motivation of employees involved in development programs.

\section{AUTHENTIC LEADERS REQUIRED IN TRAVEL AGENCIES}

In recent years, companies have faced significantly changed business environment characteristics that require a very high degree of flexibility and readiness to respond rapidly to external and internal impulses (StojanovićAleksić et al., 2012). Since a few years ago, due to the combination of organizational needs, the loss of credibility of models focused on the individual and the increase in the speed of technological advancement, changes have been made in the models of governance based on authenticity and values, organizational culture and transparency in business, resulting in the creating of the concept of authentic leaders ( $\mathrm{O}^{\prime}$ Reilly et al., 2010). Authentic leadership is the foundation of modern leadership, because it unites transformational, charismatic, spiritual and other positive leadership styles (Bass, Steidlmeier, 1999). An authentic leader is self-aware, guided by intuition, clarity and self-confidence, and works in accordance with these values. They are constantly present, take a non-judgmental attitude, show inner strength and are open to learning new skills. They know their strengths and weaknesses and have preferences for learning and thinking that helps them to connect with others and establish credibility in these relationships (Komives et al., 2006). Authentic leadership requires a person to know who it is and to be without fear or compromise in all situations. This has particular significance when it comes to travel agencies, where a large number of unforeseen circumstances can occur. An authentic leader goes beyond simple delegation and gives people explanations to define, decide and work with minimal intervention and directing. While management is focused on maintaining functionality and efficiency, leadership is based on vision, change and value (Bush, 2008). The task of the leader is to deal with the work in the course in a positive and instructive manner that provides support to employees in travel agencies, which is above all fair and transparent. The role of the leader is to help team members to articulate the options that are available.

With an authentic leadership, the focus on leadership abilities is greater than on the personality traits, so scientists agree that it is an authentic leadership skill that can be developed and influenced by the commitment of employees (Luthans, Avolio, 2003). Employee commitment is important because of all the positive outcomes generated in organizations (Schaufeli et al., 2008). An 
authentic leader in modern society views employees as a powerful source of energy that emanates from ability, personality and knowledge, and can inspire loyalty and enthusiasm for those who lead them. By their highest quality, they consider the ability to solve the complex issues of employee dedication that affects the efficiency, effectiveness, creativity and quality of work. Travel agencies with quality leaders win competition, and on the other hand, the bad performance of leadership leads to a loss of profit and inefficiency of travel agencies, due to low employee dedication and motivation, high levels of fluctuation and potentially toxic culture that can be the result of poor leadership. Leaders, who are friendly, relaxed, attentive, impartial, have supportive behaviors, which are excellent in communication, appreciate their employees, contribute to greater commitment (Yukl, 1994).

\section{SPECIFIC CHARACTERISTICS OF AUTHENTIC LEADERS}

Each organizational culture has its own and specific authentic leadership (Pavlovic, 2015). Each authentic leader functions within a branch structure and has the task of changing and adapting it according to the new needs in the environment, especially in the tourist market and in a turbulent atmosphere where travel agencies in the Republic of Serbia do their business. Changes are possible and carried out by authentic leaders (Pavlovic, 2016). George (2003), as one of the greatest supporter of the concept of authentic leadership, points out that the strategies of developing authentic leadership have become relevant and necessary for achieving the desired results, while Begley (2006) believes that authentic leaders should offer a creative response to social consumers. The aforementioned refers to the business of travel agencies and the functioning of the leaders within them.

Walumbwa et al. (2008) presented an authentic leadership through four dimensions: self-awareness, transparency in relationships, balanced processing of information and internalized morale.

Leader's self-awareness represents the starting point for the development of an authentic leader. Thus, the individual constantly reveals their knowledge, abilities, experiences, basic values, beliefs and desires (Avolio, Gardner, 2005). Self- awareness involves looking at oneself through interaction with others (Kernis, 2003). Leaders with high self-awareness use self-knowledge and opinion of other people in order to improve their management skills and ability to develop employees and their motivation (Walumbwa et al, 2010). There is a lot of research that confirms the assertion that self-awareness positively influences leadership performance (Bratton et al., 2011).

Balanced processing of information is considered as a heart of personal integrity and significantly influences decision makers and strategic actions 
THE IMPACT OF AUTHENTIC LEADERSHIP ON THE COMMITMENT OF EMPLOYEES IN TRAVEL AGENCIES IN THE REPUBLIC OF SERBIA

(Ilies et al, 2005). It implies objectively analyzing all relevant information before a decision is made (Walumbwa et al, 2010). The ability to communicate well provides the leader with certain advantages: the precision of expressing their attitudes, providing a vision, the power to encourage others to action, the skill to gain more and better use of available time (Mertins et al., 2003). At the same time, leaders need to pay equal attention to the feedback they receive about themselves and their own leadership, regardless of whether they are positive or negative information (Gardner, 2011). Human beings by nature hide their weaknesses, most often out of fear (Mazutis, Slawinski, 2008). People need to emphasize their positive qualities while hiding their weaknesses or showing them only to the close people. Leaders, who carefully analyze positive and negative information, can improve themselves, eliminate potential barriers, and give employees an example of behavior.

Internalized morale is based on internal moral values and principles, and not on external influences (Gardner, 2005). Leaders who have a high level of moral awareness, think and behave in an ethical and socially responsible way. A great deal of research has proven a positive relationship between moral reasoning and authentic leadership (Sendjaya, 2016).

Transparency implies the leader's authentic representation of himself, his thoughts, feelings and intentions for others. This ensures closeness, enters confidence, and encourages employees to act the same way. Transparency requires a person to be open to inquiries and feedback, and this is essential in the process of organizational learning (Popper, Lipshitz, 2000). The lack of transparency is a lack of integrity in behavior, i.e. there is no consistency between what the leader tells employees and what they do and what is really happening in the company (Avolio, 2016). An authentic leader maintains a high level of relevance and honest communication in all situations (Milić, 2014).

If the leaders see themselves as authentic, emphasizing transparency, balanced information processing, self-awareness and high ethical standards, employees have more opportunities and access to work-based empowerment structures, becoming more content and committed to their business (Azanza et al., 2013).

\section{THE IMPACT OF AUTHENTIC LEADERSHIP ON THE COMMITMENT OF EMPLOYEES IN TRAVEL AGENCIES}

The relationship between authentic leadership and the commitment of employees to travel agencies in the Republic of Serbia can be understood through theoretical mechanisms of positive interactions and personal 
identification of employees with the leader. Positive modeling is considered the primary means by which authentic leaders influence employees, and it includes a high level of self-awareness, balanced information processing, moral development and transparency (Walumbwa et al., 2008). As a result of authentic relationships between leaders and employees, commitment on the part of employees is developing, and the aim of this paper is to measure to what extent authentic leadership influences the commitment of employees in travel agencies in the Republic of Serbia (the starting hypothesis).

The survey was conducted by interviewing and using a questionnaire (a standardized questionnaire compiled in accordance with the research objective based on theoretical and empirical backgrounds). The questionnaire was distributed on a heterogeneous sample, which included employees in travel agencies in the Republic of Serbia. The research was conducted in the period from January to April 2019. In the presentation of the results of the first part, descriptive analysis was used. The influence of authentic leadership on the commitment of employees was tested using linear regression. Authentic leadership is an independent variable, while commitment of employees depends. The strength of the relationship between the identified aspects was determined using Pearson's correlation coefficient.

Table 1. shows the structure of respondents according to demographic characteristics.

Table 1. Demographic structure of respondents

\begin{tabular}{|c|c|c|c|c|c|}
\hline \multicolumn{2}{|c|}{ Gender } & \multicolumn{2}{|c|}{ Age } & \multicolumn{2}{|c|}{ Education } \\
\hline & & - up to 25 years & $27(24,5 \%)$ & - high school & $53(48 \%)$ \\
\hline - male & $66(60 \%)$ & - 26-35 years & $34(31 \%)$ & - college & $11(10 \%)$ \\
\hline - female & $44(40 \%)$ & - 36-45 years & $29(26 \%)$ & - Bachelor's degree & $40(36 \%)$ \\
\hline & & $\begin{array}{l}\text { - 46-55 years } \\
\text { - over } 56 \text { vears }\end{array}$ & $\begin{array}{l}16(14,5 \%) \\
4(4 \%)\end{array}$ & - Master's degree & $6(6 \%)$ \\
\hline
\end{tabular}

Source: Author's calculation based on SPSS 20.0

Tables 2. and 3. show arithmetic mean and mean values of standard deviation, reliability and correlation of variables.

Table 2. Arithmetic meanings and standard deviation

\begin{tabular}{|c|c|c|}
\hline Dimension & Mean & St. dev \\
\hline Self-awareness & 3,27 & 0,67 \\
\hline Balanced processing of information & 3,79 & 0,96 \\
\hline Internalized morale & 3,89 & 0,93 \\
\hline Transparency & 3,80 & 0,99 \\
\hline Employee commitment & 3,75 & 0,88 \\
\hline
\end{tabular}

Source: Author's calculation based on SPSS 20.0 
THE IMPACT OF AUTHENTIC LEADERSHIP ON THE COMMITMENT OF EMPLOYEES IN TRAVEL AGENCIES IN THE REPUBLIC OF SERBIA

Table 3. Correlations of variables

\begin{tabular}{|c|c|c|c|c|c|}
\hline Dimension & $\begin{array}{c}\text { Self- } \\
\text { awareness }\end{array}$ & $\begin{array}{c}\text { Balanced } \\
\text { processing of } \\
\text { information }\end{array}$ & $\begin{array}{c}\text { Internalized } \\
\text { morale }\end{array}$ & Transparency & $\begin{array}{l}\text { Employee } \\
\text { commitment }\end{array}$ \\
\hline $\begin{array}{c}\text { Self- } \\
\text { awareness }\end{array}$ & 1 & & & & \\
\hline $\begin{array}{c}\text { Balanced } \\
\text { processing of } \\
\text { information }\end{array}$ & 0.366 & 1 & & & \\
\hline $\begin{array}{c}\text { Internalized } \\
\text { morale }\end{array}$ & 0.517 & 0.406 & 1 & & \\
\hline Transparency & 0.610 & 0.660 & 0.669 & 1 & \\
\hline $\begin{array}{l}\text { Employee } \\
\text { commitment }\end{array}$ & 0.625 & 0.348 & 0.419 & 0.632 & 1 \\
\hline
\end{tabular}

Source: Author's calculation based on SPSS 20.0

The results of the correlation analysis indicate the link between authentic leadership and the commitment of employees to travel agencies. Correlation analysis indicated a moderately significant correlation between the variables. The hypothesis was tested by checking the value of the significance test and the regression coefficient. The results show positive correlations between the variables. It has been established that the commitment of employees in travel agencies is significantly influenced by the following three dimensions of authentic leadership: self-interest $(\beta=0.625)$, transparency $(\beta=0.632)$ and internalized morality $(\beta=0.419)$, while the value that shows the impact of balanced processing of information on commitment is lower $(\beta=0.348)$.

The results of the research have empirically confirmed that there is a positive effect of authentic leadership on the employees in the travel agencies $(\mathrm{R}=$ $0.85 ; \mathrm{R} 2=72 \% ; \mathrm{p}<0.01 ; \beta=0.504)$. The surveyed employees believe that leaders have distinctive characteristics and abilities of authentic leaders. This proves the theoretical assumptions that leaders who are self-aware and transparent have a positive connection with employee dedication (Gardner et al, 2005). Emery and Barker (2007) argued that authentic leadership is an important factor for increasing job satisfaction among employees. Peterson et al. (2012) found that authentic leadership has a positive effect on the engagement of employees. Transparency and internalized morality according to Loa et al. (2010) are not significantly related to the commitment of employees, while self-awareness and balanced information processing have a significant and positive relationship with the continued commitment of employees. When the projections of employee and leader values are equal, employee dedication increases, talented potential employees are attracted and existing ones retained (Sabir et al., 2011). A general research by various authors shows that a lack of authenticity can have negative consequences on employee performance and employee commitment (Milić, 2014). 


\section{CONCLUSION}

The conditions, in which today's travel agencies operate, have become changeable and what will happen in the upcoming period can often not be foreseen. Therefore, the task that is being put in front of the leaders is not at all easy, regardless of whether they run a small or large travel agency (a subagent or a tour operator). Authentic leadership is considered one of the ways to improve the situation in travel agencies in the Republic of Serbia. The effectiveness of the leaders in travel agencies is of primary importance for the survival of companies on the market. When developing the leadership skills of current and future managers, there is no emphasis on soft skills or on affable bosses. The essence is the development of leadership competencies and investing in the performance, productivity and profitability of tourist agencies leading to sustainable growth and competitive advantage. Travel agencies seeking to achieve a competitive advantage on the market should shift the focus of training for leaders to the initiative to develop the skills of authentic leadership. It is very important that the leaders in the travel agencies act according to the characteristics and skills of the authentic leaders. Travel agencies that want to improve employees' commitment should focus on developing the skills of an authentic leader. Creating an emphasis on selfawareness, transparency, internalized morale and processing information in an adequate way, creates an ethical spiral of growth and development, leads to increased self-confidence, self-confidence and the success of an individual, team and a complete travel agency. Creating respect without fear and developing sustainable relationships, based on great trust, are the goals of an authentic leader that strives to win in all situations.

The limitation of this work is reflected in a small sample and a narrow territorial distribution (research should be carried out within the wider population). The second limitation relates to the fact that only one branch is included in the tourism industry. Future research should cover diverse businesses that operate in tourism and hotel industry.

\section{REFERENCES}

1. Armstrong, M., 1999. Human resources management practice. London: Kogan Page.

2. Avolio, B.J., 1999. Full Leadership Developement: Building the vital forces in organization. Sage: Thousand Oaks, UK.

3. Avolio, B.J., Gardner, W.L., 2005. Authentic leadership development: Getting to the root of positive forms of leadership. Leadership Quarterly, 16, pp. 315-338.

4. Avolio, B.J., 2016. Candor and transparency: Aligning your leadership constellation. People \& Strategy, 39(4), pp. 16-21. 
THE IMPACT OF AUTHENTIC LEADERSHIP ON THE COMMITMENT OF EMPLOYEES IN TRAVEL AGENCIES IN THE REPUBLIC OF SERBIA

5. Azanza, G., Moriano, J.A., Moler, F., 2013. Authentic leadership and organizational culture as drivers of employees' job satisfaction, Journal of Work and Organizacional Psychology, 29(2), pp. 25-30.

6. Bass, B.M., Steidlmeier, P., 1999. Ethics, character, and authentic transformational leadership. The Leadership Quarterly, 10, pp. 181217

7. Begley, P., 2006. Self knowledge, capacity and sensitivity: Prerequisites to authentic leadership by school principals, Journal of Educational Administration and Leadership, 44, pp. 570-589.

8. Блешић, И., Пивац, Т., Дивјак, Т., 2017. Ефекти задовољства послом на организациону приврженост запослених у хотелијерству, Пословна економија, 9 (2), стр. 114-132.

9. Bratton, V. K., Dodd, N. G., Brown, F. W., 2011. The impact of emotional intelligence on accuracy of self-awareness and leadership performance. Leadership \& Organization Development Journal, 32(2), pp. 127-149.

10. Bush, T., 2008. From management to leadership: semantic or meaningful change? Educational Management Administration \& Leadership, 36(2), pp. 271-288.

11. Emery, C.R., Barker, K.J. 2007. The effect of transactional and transformational leadership styles on the organizational commitment and job satisfaction of customer contact personnel. Journal of Organizational Culture, Communication \& Conflict, 11(1), pp. 77-90.

12. Ford, J., Harding, N., 2011. The impossibility of the 'true self' of authentic leadership. Leadership, 7(4), pp. 463-479.

13. Fornes, S.L., Rocco, T.S., Wollard, K.K., 2008. Workplace commitment: A conceptual model developed from integrative review of the research. Human Resource Development Review, 7(3), pp. 339357.

14. Gardner, W., Avolio, B., Luthans, F., May, D.R., Walumbwa, F., 2005. Can you see the real me? A self-based model of authentic leader and follower development, The Leadership Quarterly, 16, pp. 343372 .

15. Gardner, W., Cogliser, C., Davis, K., Dickens, M., 2011. Authentic leadership: A review of the literature and research agenda, The Leadership Quarterly, 22, pp. 1120-1145.

16. George, B., 2003. Authentic leadership: Rediscovering the secrets to creating lasting value. San Francisco: Jossey-Bass.

17. George, J. M., Jones, G. R., 2012. Understanding and Managing Organizational Behavior. New York: Prentice Hall.

18. Ineson, E. M., Benke, E., Laszlo, J., 2013. Employee loyality in Hungarian hotels, International journal of Hospitality Management, 32, pp. 31-39. 
19. Ilies, R., Morgeson, F.P., Nahrgang, J.D., 2005. Authentic leadership and eudaemonic wellbeing: understanding leader-follower outcomes. The Leadership Quarterly, 16, pp. 373-394.

20. Johns, G., Saks, A. M., 2005. Organizational behaviour: understanding and managing life at work. Pearson Prentice Hall.

21. Kernis, M.H., 2003. Toward a conceptualization of optimal selfesteem. Psychological Inquiry, 14, pp. 1-26.

22. Komives, S. R., Lucas, N., McMahon, T. R., 2006. Exploring leadership: For college students who want to make a difference. San Francisco: Jossey-Bass.

23. Luthans, F., Avolio, B. J., 2003. Authentic leadership: A positive developmental approach. In: K. S. Cameron, J. E. Dutton, R. E. Quinn (Eds.), Positive organizational scholarship (pp. 241-261). San Francisco, CA: Barrett-Koehler.

24. Mazutis, D., Slawinski, N., 2008. Leading Organizational Learning Through Authentic Dialogue. Management Learning, 39(4), pp. 437456.

25. Menken, J., 2012. What All Great Leaders Have. New York: Executive Intelligence.

26. Mertins K., Heisig P., Worbeck J., 2003. Knowledge Management, Springer

27. Meyer, J. P., 2014. Employee Commitment, Motivation, and Engagement: Exploring the Links, In M. Gagne (Ed.): The Oxford Handbook of Work Engagement, Motivation, and Self-Determination theory. New York, NY: Oxford University Press, pp. 33-49.

28. Milić, B., 2014. Influence of Authentic Leadership on Employees Affective Commitment. Human Resource Management Conference Proceeding Belgrade, pp. 61-69.

29. Northouse, P.G, 2017. Leadership-Theory and Practice, ( $8^{\text {th }}$ ed.), Sage: Thousand Oaks, UK.

30. O'Reilly, C. A., Caldwell, D. F., Chatman, J. A., Pencil, M., \& Self, W. (2010). How Leadership Matters: The Effects of Leaders' Alignment on Strategy Implementation. The Leadership Quarterly, 21, pp. 104-113.

31. Овесни, К., 2014. Посвећеност запослених - елемент евалуације и ослонац стратегије унапређивања квалитета развоја људских ресурса из: Зборника Модели проценивана и стратегије унапређивања квалитета образовања одраслих у Србији, Београд: Филозовски факултет, стр. 155-173.

32. Pavlovic, N., 2015. Authentic Leadership in Educational Institutions, International Journal for Quality Research, 9(2), pp. 309-322.

33. Pavlovic, N., 2016. Are authentic leaders satisfied with their job?, International Journal for Quality Research, 10 (2), pp. 325-340. 
THE IMPACT OF AUTHENTIC LEADERSHIP ON THE COMMITMENT OF EMPLOYEES IN TRAVEL AGENCIES IN THE REPUBLIC OF SERBIA

34. Peterson, S. J., Walumbwa, F. O., Avolio, B. J., Hannah, S. T., 2012. The relationship between authentic leadership and follower job performance: The mediating role of follower positivity in extreme contexts. The Leadership Quarterly, 23, pp. 502-516.

35. Popper, M., Lipshitz, R., 2000. Installing mechanisms and instilling values: the role of leaders in organizational learning. The Learning Organization, 7(3), pp. 35-142.

36. Porter, L. W., Steers, R. M., Mowday, R. T., Boulian, P. V., 1974. Organizational commitment, job satisfaction and turnover among psychiatric technicians. Journal of Applied Psychology, 59, pp. 603-609.

37. Sabir, M, Sohail, A., Khan, M., 2011. Impact of leadership style on Organization commitment. Journal of Economics and Behavioral Studies, 3, pp. 145-152.

38. Sendjaya, S., Pekerti, A., Hartel, C., Hirst, G., Butarbutar, I., 2016. Are authentic leaders always moral? The role of Machiavellianism in the relationship between authentic leadership and morality. Journal of Business Ethics, 133(1), pp. 125-139.

39. Schaufeli, W., Bakker, A. Salanova, M., 2006. The Measurement of Work Engagement With a Short Questionnaire, Educational and Psychological Measurement, 66(4), pp. 701-716.

40. Стојановић-Алексић, В., Бабић, В., Ерић, Ј., 2012. Харизматско лидерство- концепт, извори и ефекти. Теме, 36(1), стр. 205-217.

41. Yukl, G., 1994. Leadership in Organizations (3rd ed.), Englewood Cliffs: Prentice-Hall

42. Yukl, G., Tracey, J. B., 1992. Consequences of Influence Tactics Used with Subordinates, Peers, and the Boss. Journal of Applied Psychology, 77, pp. 525-535.

43. Walumbwa, F.O., Avolio, B.J., Gardner, W.L., Wernsing, T.S. Peterson, S.J., 2008. Authentic leadership: Development and validation of a theory-based measure. Journal of Management, 34, pp. 89-126.

44. Walumbwa, F.O., Wang, P., Wang, H., Schaubroeck, J., Avolio, B.J., 2010. Psychological processes linking authentic leadership to follower behaviors. The Leadership Quarterly, 21, pp. 901-914.

Received: 4 May, 2019

Accepted: 18 June, 2019

Rad je primljen: 04.05.2019.

Prihvaćen za objavljivanje: 18.06.2019. 
